\title{
《書 評》
}

『カラスの自然史【系統から遊び行動まで】』樋口広芳・黒沢令子編著. 2010 年. 北海 道大学出版会. 280 ページ．3,150 円. ISBN978-4832981966.

カラスについてはその都市鳥としての側面に注目が集まりがちであるが，自然科学としてあ 着実に研究は進められて来た。そ机ら最新の研究を各分野の第一人者が執筆し, 且つ日本語で 読める総説として, 本書は貴重なあのである。またカラスについて知りたいならば是非とあ読 んでおくべきスタンダードと言える。

第I部ではカラス類の進化，そして種分化について，系統学的な知見，そして手法が解説さ れる。また進化生態学的な視点屯興味深い。

第 II 部では森下・樋口らによる PHS を用いた八シブトガラスの追跡調査が紹介されてい る。カラスの日常的なスケール感を知ることのできる章である。続く吉田によるハシボソガラ ス・ハシブトガラスの種間関係についての総説は非常にまとまりが良く, 種間競争や環境選択 に関するこれまでの知見と最新の研究を一気に読むことができる。

第 III 部, 「栄養塩の供給から見る, 都市における八シブトガラスの役割」(藤田) と「海辺にお ける八シボソガラスの採食とその生態学的意義」(堀)には, 大仰に言えば意表を衝かれた。栄養 塩の循環についてはカラスだけを取り上げる必要はないのだろうが, カラスの存在は個体数べー スであバイオマスベースであ巨大であろう。また人間の食べ残しや家畜飼料を餌とする事でグ ローバルな栄養循環をもたらしている, という認識が面白い。そして堀は「貝落とし」といった特 定の行動から見られがちであった海岸での生態を, 磯の生態系の観点から論じている。ハシボり ガラスが 1 日に 3,500 円屯のウ二を食べるとは初めて知った。評者が 90 円のメロンパンを瑟っ ている目の前で骨付きソーセージを食べるカラスに殺意を覚えて以来の衝撃であるが, 続く「カ ラスの果樹園」(長谷川) 屯含め, 生態系に扔けるカラスの存在を改めて認識させられた。否， あ れほど何であ食べてどこにでもいる鳥が生態系の中で無視できる筈もないのだが。

第 IV 部，10 章（吉田），11 章（中村）は㭙に当てられている。正直，「埘は難しいな」之感 じるのだが，同時に筆者らの粘り強い調査によって侍の移動，集合に関わるキューが特定され つつある事あ読み取れる

12 章 (伊澤), 13 章 (杉田) は世界的にもホットな話題之なったカラスの認知能力に関する記述 である。中でも伊澤による個体関係の認知に関する研究は一般書では初の紹介ではなからうか。

第 III 部 9 章の地域文化（樋口），第 IV 部 13 章の遊び（黒沢）は興味の尽きないテーマである が, 同時に難しさを感じた。黒沢が触れているように, 個体の行動がどのように伝達・継承され て行くかを今後検証して行く必要があ万う。この点については 15 章のミーム論からの考察を合 わせて読むのが面白い。いずれにせよ, こういった興味深い行動への切り口として, 客観的な記 録の蓄積は不可欠なあのでああろう。なお 15 章は世界的に著名なカラス研究者である Marzulff 之黒沢による，文化人類学をあ視野に入れたパートであり，文化史という点であ興味深い。

内容が多彩なため各章がやや短いのは残念であるが, 読み足りない部分は充実した引用文献 リストを活用したい。

（文中敬称略；松原 始 評） 